\title{
Mombaça grass yield as a function of nitrogen fertilization based on the use of the chlorophyll meter
}

\author{
Produtividade do capim mombaça em função \\ da adubação nitrogenada baseada no uso do \\ clorofilômetro
}

\begin{abstract}
Lorrayne Lays Ferreira Leite ${ }^{1 ;}$ Clarice Backes²; Leandro José Grava de Godoy3; Alessandro José Marques Santos²; Arthur Gabriel Teodoro4*; Lucas Matheus Rodrigues ${ }^{1}$; Cinthya Cristina Fernandes de Resende ${ }^{5}$; Adriana Aparecida Ribon ${ }^{2}$
\end{abstract}

\section{Highlights}

The importance of efficient nitrogen fertilization of Mombaça grass.

The ISN obtained with the chlorophyllometer provides greater agronomic efficiency.

ISN90\%, was the band that showed the highest efficiency.

\section{Abstract}

The objective of this study was to evaluate the yield and agronomic efficiency of mombaça grass achieved with the management of nitrogen fertilization, based on the nitrogen sufficiency index (NSI) calculated using measurements obtained with a chlorophyll meter. The experiment was conducted in the field, in São Luís de Montes Belos - GO, Brazil, from November 2016 to May 2018, as a randomized-block design with six treatments and five replicates. Treatments consisted of six $\mathrm{N}$ fertilization management strategies (M), namely, M1 - reference, with $150 \mathrm{~kg} \mathrm{ha}^{-1} \mathrm{~N}$ per application; M2 - recommended, with $50 \mathrm{~kg} \mathrm{ha}^{-1} \mathrm{~N}$ per application; M3 - 50 kg ha-1 N when NSI < 98\%; M4 - 50 kg ha-1 N when NSI < 94\%; M5 - $50 \mathrm{~kg} \mathrm{ha}^{-1} \mathrm{~N}$ when NSI < 90\%; and M6 - control treatment, without $\mathrm{N}$ application. The NSI was monitored based on the relative chlorophyll content obtained with the chlorophyll meter. Forage canopy height, tiller density, and yield were evaluated. At the end of the 2nd cycle, the recommended, reference, NSI98\%, NSI94\%, and NSI90\% treatments had received $1,050,350,300,250$, and $0 \mathrm{~kg} \mathrm{~N} \mathrm{ha}^{-1}$. Control treatment obtained the lowest dry biomass yield, whereas the

1 M.e, Universidade Estadual de Goiás, UEG, Campus Oeste, São Luis de Montes Belos, GO, Brazil. E-mail: lorraynnelays@ hotmail.com; lucasmrzoo@gmail.com

2 Profs. Drs., UEG, Campus Oeste, São Luis de Montes Belos, GO, Brazil. E-mail: clarice.backes@ueg.br; alessandro. santos@ueg.br; adriana.ribon@ueg.br

${ }^{3}$ Prof. Dr., Universidade Estadual Paulista Júlio de Mesquita Filho, UNESP, Campus de Registro, SP, Brazil. E-mail: leandro.godoy@unesp.br

${ }^{4}$ Student of the Doctoral Course of the Postgraduate Program Zootecnia, Escola de Veterinária e Zootecnia, Universidade Federal de Goiás, EVZ/UFG, Goiânia, GO, Brazil. E-mail: arthur_teodoro@hotmail.com

${ }^{5}$ Graduate, UEG, Campus Oeste, São Luis de Montes Belos, GO, Brazil. E-mail: cinthyaresende@hotmail.com

* Author for correspondence

Received: May 28, 2021 - Approved: Aug. 25, 2021 
recommended, NSI98\%, and NSI94\% treatments showed the highest. Thus, $\mathrm{N}$ doses between 1,950 and $300 \mathrm{~kg} \mathrm{ha}^{-1}$, in the second cycle, provided statistically equivalent yields in mombaça grass. Considering the DM of both evaluation cycles, the highest yield was achieved with the NSI98\% and NSI94\% treatments. The application of $\mathrm{N}$ doses of 250 to $1050 \mathrm{~kg} \mathrm{ha}^{-1}$ provided similar yields. Therefore, the adoption of a nitrogen sufficiency index below $98 \%$ and $94 \%$ as a parameter allows a reduction and rational use of nitrogen fertilizer. Key words: Antifungal effect. Essential oil. Spices.

\section{Resumo}

Objetivou-se com esse trabalho avaliar a produtividade e eficiência agronômica do capim Mombaça, obtidas com o manejo da adubação nitrogenada, baseada no ISN calculado com as medidas do clorofilômetro. O experimento foi conduzido a campo em São Luís de Montes Belos, GO, de novembro de 2016 a maio de 2018. O delineamento utilizado foi em blocos casualizados, com seis tratamentos e cinco repetições. Os tratamentos foram constituídos por seis manejos de adubação nitrogenada: M1 - Referência com aplicação de $150 \mathrm{~kg} \mathrm{ha}^{-1} \mathrm{~N}$ por aplicação; M2 - Recomendado com $50 \mathrm{~kg} \mathrm{ha}^{-1} \mathrm{~N}$ por aplicação; M3 - 50 kg ha-1 de N quando o ISN < 98\%, M4 - 50 kg ha-1 de N quando o ISN < 94\%, M5 - 50 kg ha-1 de N quando o ISN < 90\% e M6 - Tratamento controle, sem aplicação do N. O monitoramento do ISN foi realizado em função do Índice Relativo de Clorofila (IRC) obtido com o clorofilômetro. Avaliou-se altura do dossel forrageiro, densidade populacional de perfilhos e produtividade. Para matéria seca (MS), ao fim do $2^{\circ}$ ciclo, os tratamentos recomendados, referência, ISN 98, 94 e 90\% haviam totalizado 1.050, 350, 300, 250 e $0 \mathrm{~kg} \mathrm{~N} \mathrm{ha}^{-1}$. O tratamento controle apresentou a menor produção e os tratamentos recomendado, ISN 98\% e 94\% as maiores. Portanto doses entre 1.950 e $300 \mathrm{~kg} \mathrm{~N} \mathrm{ha}^{-1}$, no segundo ciclo, promoveram produções estatisticamente equivalentes no capim Mombaça. Considerando a MS dos dois ciclos de avaliação, as maiores produtividades foram nos tratamentos ISN 98\% e 94\%. A aplicação de doses de 250 a $1050 \mathrm{~kg} \mathrm{~N} \mathrm{ha}^{-1}$ proporcionaram produções semelhantes. Portanto o uso do ISN 98\% e 94\% como parâmetros possibilita redução e uso racional do fertilizante nitrogenado.

Palavras-chave: Clorofila. Forrageiras tropicais. Nitrogênio.

\section{Introduction}

In pastures, yield can vary according to the plant species. However, in addition to genetics, favorable environmental and management conditions are required, as these are key points for the viability of any pasturebased production system (Fagundes et al., 2011; Hanrahan et al., 2018).

Among the tropical forages used in dairy and meat production systems, mombaça grass (Panicum maximum Jacq. cv. Mombaça) stands out due to its high yield potential and nutritional value (Garcia et al., 2011). However, this forage is considered highly demanding, with good results achieved mainly when nitrogen (N) is used (Galindo, Buzetti, Teixeira, Dupas, \& Ludkiewicz, 2017), thereby warranting assertive fertilization management.

Nitrogen is involved in the photosynthetic process, where it participates directly in the chlorophyll molecule, increasing photosynthetic efficacy and dry matter (DM) production (C. H. O. Macedo et al., 2012). 
According to Factori et al. (2017), $\mathrm{N}$ is the element of greatest importance for the growth of forages, and $\mathrm{N}$ doses of 300 to 400 $\mathrm{kg}$ ha-1 promoted an increase in the height of mombaça grass plants. Canto, Barth, Pancera, Gasparino and Boleta (2012), found positive increases in the DM production and tiller population of mombaça grass as a result of $\mathrm{N}$ fertilization.

Due to the importance of $\mathrm{N}$ for plant productivity, fertilization costs, and potential losses of the nutrient in the soil, efficient management of $\mathrm{N}$ fertilization is essential for the viability of an agriculture-livestock activity (Ryan, Hennessy, Murphy, Boland, \& Shaloo, 2011). Some methodologies have been investigated with a view to increasing $\mathrm{N}$ use efficiency, one of them being the assessment of the plant nutritional status with the use of the chlorophyll meter. This instrument measures the chlorophyll content indirectly, based on optical properties of the leaves, and these measurements are then correlated with the $\mathrm{N}$ content of the leaves of forage plants (Silva et al., 2011).

One way to regulate the measurements made with the chlorophyll meter is by calculating the nitrogen sufficiency index
(NSI), which is determined as the average of the measurements taken on plants in an area to be fertilized with $\mathrm{N}$ divided by the average of the readings in a reference area that has already been fertilized with an adequate $\mathrm{N}$ dose (Silveira \& Ferreira, 2016).

The objective of this study was to evaluate the yield and agronomic efficiency of mombaça grass achieved with the management of $\mathrm{N}$ fertilization based on the $\mathrm{NSI}$ calculated using measurements obtained with a chlorophyll meter.

\section{Material and Methods}

The experiment was conducted in the field, in São Luís de Montes Belos - GO, Brazil (16³2'30" S, 50²5'21" W, 569 m asl), from November 2016 to May 2018. The region has an Aw climate, according to the Köppen classification, with an average temperature of $23.5^{\circ} \mathrm{C}$ and an average annual rainfall of $1,785 \mathrm{~mm}$, which is concentrated between the months from October to March (Alvares, Stape, Sentelhas, Gonçalves, \& Sparovek, 2013). Temperature and precipitation data during the experiment were recorded (Figure 1). 


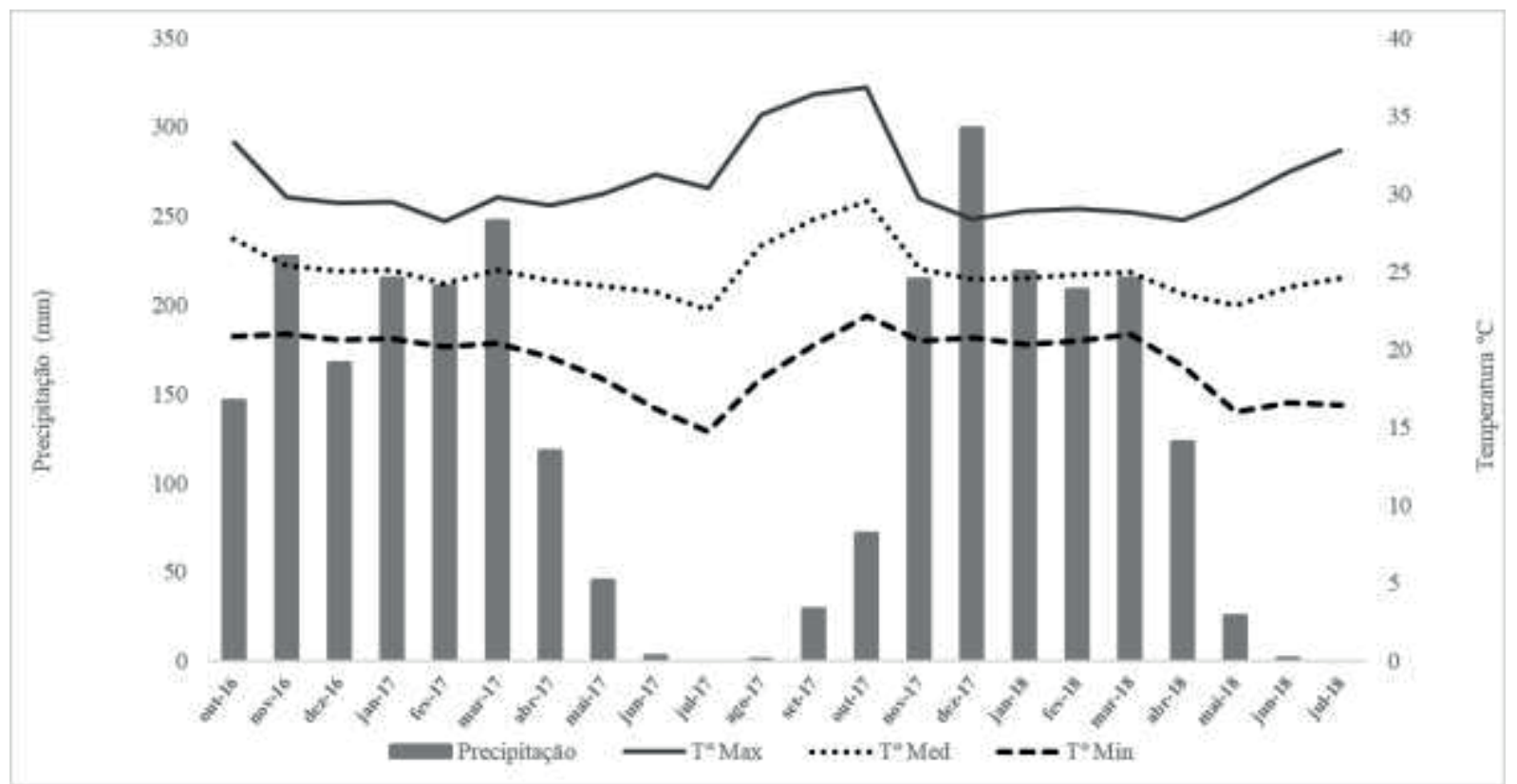

Figure 1. Average and usable temperature data during the period of conducting the experiment (São Luís de Montes Belos, GO).

The soil where the experiment was implemented was classified as a Dystrophic Red Latosol (Typic Haplorthox), on mild, undulating relief (Empresa Brasileira de Pesquisa Agropecuária [EMBRAPA], 2018). For initial chemical characterization, samples of the 0-0.20-m layer were collected from the entire experimental area and analyzed methodology EMBRAPA (1997).

Soil chemical and particle-size analysis performed in the $0-0.20-\mathrm{m}$ layer before the implementation of the experiment revealed the following properties: $\mathrm{pH}(\mathrm{CaCl} 2): 5.3 ; \mathrm{Ca}$, $\mathrm{Mg}, \mathrm{H}+\mathrm{Al}, \mathrm{K}$, and CEC: 6.3, 0.9, 3.3, 0.194, and 10.69 cmolc dm$^{-3}$, respectively; $P$ (Mehlich I), $\mathrm{Na}, \mathrm{S}, \mathrm{B}, \mathrm{Cu}, \mathrm{Fe}, \mathrm{Mn}$, and $\mathrm{Zn}:$ 7.0, 3.0, 4.0, 0.1, $2.0,25,61$, and $0.9 \mathrm{mg} \mathrm{dm}-3$ respectively; 20.0 $\mathrm{g} \mathrm{kg}^{-1}$ organic matter; $69 \%$ base saturation; and 390, 320, and $290 \mathrm{~g} \mathrm{~kg}^{-1}$ sand, silt, and clay, respectively.
Conventional soil preparation procedures were carried out in the experimental area, consisting of one plowing and two harrowing operations. On 11/19/2016, the forage grass Panicum maximum Jacq. cv. Mombaça was sown at a density of $4.8 \mathrm{~kg} \mathrm{ha}^{-1}$, with a $40 \%$ crop value. Based on soil analysis, liming was not performed. Base fertilization (formation) consisted of the application of $110 \mathrm{~kg} \mathrm{ha}^{-1} \mathrm{P}_{2} \mathrm{O}_{5}$ in the form of triple superphosphate and $60 \mathrm{~kg} \mathrm{ha}^{-1} \mathrm{~K}_{2} \mathrm{O}$ in the form of potassium chloride.

The experiment was laid out in a randomized-block design with six treatments and five replicates. Treatments consisted of six $\mathrm{N}$ fertilization management strategies (M), namely, M1 - reference, with application of $150 \mathrm{~kg} \mathrm{ha}^{-1} \mathrm{~N} ; \mathrm{M} 2$ - recommended, with the $\mathrm{N}$ dose of $50 \mathrm{~kg} \mathrm{ha}^{-1}$ recommended by Vilela, Soares, Sousa and Macedo (2004); M3 - 50 kg 
ha-1 $^{-1}$ when NSI<98\%; M4 - $50 \mathrm{~kg} \mathrm{ha}^{-1} \mathrm{~N}$ when $\mathrm{NSI}<94 \%$; $\mathrm{M} 5$ - $50 \mathrm{~kg} \mathrm{ha}^{-1} \mathrm{~N}$ when $\mathrm{NSI}<90 \%$; and M6 - control, without $\mathrm{N}$ application. Urea was used as the $\mathrm{N}$ source. All fertilizer applications were carried out manually, after lowering the grass. The plots measured $3 \times$ $3 \mathrm{~m}$, considering a bordering area of $1 \mathrm{~m}$ on each side.

The NSI was monitored based on the relative chlorophyll content (RCC), which was obtained using a portable chlorophyll meter (Clorofilog, Falker) on the index leaves of the grass. These correspond to the first and second newly expanded leaves of the tiller, from 10 plants per plot, totaling 20 leaves sampled. This monitoring procedure was carried out on the same day as the other evaluations.

The NSI was calculated considering the RCC values obtained with the chlorophyll meter of each plot (LA), as a function the reference plot (REF), using the following equation: $\mathrm{NSI}(\%)=(\mathrm{LA} / \mathrm{REF}) \times 100$.

To standardize the plots, the grass was harvested on $01 / 17 / 2017$ at a height of 0.40 m. Subsequently, $150 \mathrm{~kg} \mathrm{~N} \mathrm{ha-1}$ were applied in the reference treatment and $50 \mathrm{~kg} \mathrm{~N}$ ha-1 in the others, except control, which did not receive $\mathrm{N}$ fertilization. The first evaluation took place in February 2017. The experimental period was divided into two production cycles, considering the rainy season in the region. Evaluations performed from February to September 2017 constituted the first cycle, whereas the second cycle comprised the period from October 2017 to May 2018.

Forage canopy height, tiller density, and yield were evaluated in the grass, in a usable area of $4 \mathrm{~m}^{2}$. The agronomic efficiency of $\mathrm{N}$ fertilization was also calculated.
Height was determined using a graduated ruler at five random points in the usable area. A sheet of paper was cast over the leaves and height was measured at its midpoint. The process was repeated for the other measurements. In total, 16 evaluations were carried out from February 2017 to May 2018.

Yield was determined in an area bounded by a $1 \times 1-\mathrm{m}$ frame, at $0.40 \mathrm{~m}$ above the ground level. The fresh biomass within this area was weighed and a 300-g sample was dried in a forced-air oven at $65^{\circ} \mathrm{C}$ until reaching a constant weight to obtain the dry biomass of the grass, which was then extrapolated to one hectare. Twelve harvests were conducted in total, in the months of February, March, April, May, June, November, and December of 2017 and January, February, March, April, and May of 2018.

To determine the tiller density, all live tillers were counted manually, within an area bounded by a $0.25 \times 0.25-\mathrm{m}$ frame, in each of the plots. Three counts were made at different random points in the $1-\mathrm{m}^{2}$ area. Tiller measurements were carried out in the same periods as the yield assessments, after the grass was lowered.

Collections and evaluations were undertaken every 28 days, with the purpose of simulating a rotated-grazing environment. The criterion for harvesting was grass height exceeding $0.40 \mathrm{~m}$. In the months of July, August, September, and October 2017, the grass did not reach the height for harvest, due to lack of rainfall (Figure 1).

Nitrogen fertilization was always carried out after the harvests, in the quantities of established for each treatment (Table 1). 
Table 1

Amount of $\mathrm{N}$ applied as topdressing $\left(\mathrm{kg} \mathrm{ha}^{-1}\right)$ in each treatment, in each evaluated harvest, showing the total $\mathrm{N}$ received during the experiment, in the years 2017 and 2018

\begin{tabular}{|c|c|c|c|c|c|c|}
\hline \multirow[b]{2}{*}{ Harvest } & \multirow[b]{2}{*}{ Control } & \multicolumn{3}{|c|}{ Treatment } & \multirow[b]{2}{*}{ NSI94\% } & \multirow[b]{2}{*}{ NSI90\% } \\
\hline & & Reference & Recommended & NSI98\% & & \\
\hline \multicolumn{7}{|c|}{ 1st cycle } \\
\hline Base fertilization $(01 / 17 / 17)$ & 0 & 150 & 50 & 50 & 50 & 50 \\
\hline 1st $(02 / 14 / 17)$ & 0 & 150 & 50 & 0 & 0 & 0 \\
\hline 2nd (03/17/17) & 0 & 150 & 50 & 0 & 0 & 0 \\
\hline 3rd (04/13/17) & 0 & 150 & 50 & 0 & 0 & 0 \\
\hline 4th $(05 / 11 / 17)$ & 0 & 150 & 50 & 50 & 0 & 0 \\
\hline 5th $(06 / 11 / 17)$ & 0 & 150 & 50 & 0 & 0 & 0 \\
\hline Total (1st cycle) & & 900 & 300 & 100 & 50 & 50 \\
\hline \multicolumn{7}{|c|}{ 2nd cycle } \\
\hline 6 th $(11 / 17 / 17)$ & 0 & 150 & 50 & 50 & 50 & 0 \\
\hline 7 th $(12 / 13 / 17)$ & 0 & 150 & 50 & 50 & 0 & 0 \\
\hline 8th $(01 / 11 / 18)$ & 0 & 150 & 50 & 50 & 50 & 0 \\
\hline 9th $(02 / 09 / 18)$ & 0 & 150 & 50 & 50 & 50 & 0 \\
\hline 10th $(03 / 08 / 18)$ & 0 & 150 & 50 & 50 & 50 & 0 \\
\hline 11th $(04 / 12 / 18)$ & 0 & 150 & 50 & 50 & 50 & 0 \\
\hline 12th $(05 / 25 / 18)$ & 0 & 150 & 50 & 0 & 0 & 0 \\
\hline Total (2nd cycle) & 0 & 1,050 & 350 & 300 & 250 & 0 \\
\hline Total (2 cycles) & 0 & 1,950 & 650 & 400 & 300 & 50 \\
\hline
\end{tabular}

Agronomic efficiency (AE) was calculated per cycle of mombaça grass, by subtracting the dry biomass (DB) produced in the treatment without $\mathrm{N}$ fertilizer from that produced in the treatment with $\mathrm{N}$ fertilizer and dividing the result by the $\mathrm{N}$ dose applied, with results expressed $\mathrm{kg} \mathrm{BM} \mathrm{kg} \mathrm{N}^{-1}$ (Fageria, Slaton, \& Baligar, 2003).

Results were subjected to analysis of variance and mean comparison by Tukey's test at $5 \%$ probability, using Sisvar 5.6 statistical software (Ferreira, 2014).

\section{Results e Discussion}

Nitrogen fertilization had little influence on the height of mombaça grass, with statistical differences being observed only in four of the 16 evaluated periods. In the first cycle, the treatments influenced only the 6 th growth, with the highest mean obtained by the reference treatment (Table 2). However, for Marandu grass (Urochloa brizantha) Silva, Costa, Faquim, Oliveira and Bernardes (2013), observed a greater influence of nitrogen fertilization on grass height, finding the highest mean height values at a dose of $300 \mathrm{~kg} \mathrm{ha}^{-1} \mathrm{~N}$ year $^{-1}$, showing an average increase of $120 \%$, in three years. 
At the 11th growth, in the second cycle, only the height means obtained in the reference and NSI98\% treatments were higher than those obtained in control treatment. At the 12th and 16th growths, none of the treatments surpassed control for plant height. Pasture height of Panicum maximum (Tanzania, Mombaça, and Massai cultivars) can be positively correlated with animal weight gain (Brâncio et al., 2003).

\section{Table 2}

Plant height $(\mathrm{cm})$ of mombaça grass in the two evaluated cycles as a function of nitrogen fertilization, based on the chlorophyll meter, in the years 2017 and 2018

\begin{tabular}{|c|c|c|c|c|c|c|c|c|}
\hline \multirow[b]{2}{*}{ Treatment } & \multicolumn{8}{|l|}{ Growth } \\
\hline & $\begin{array}{c}1 \text { st } \\
\text { (Feb/17) }\end{array}$ & $\begin{array}{c}\text { 2nd } \\
(\mathrm{Mar} / 17)\end{array}$ & $\begin{array}{c}3 r d \\
(A p r / 17)\end{array}$ & $\begin{array}{c}\text { 4th } \\
\text { (May/17) }\end{array}$ & $\begin{array}{c}\text { 5th } \\
\text { (Jun/17) }\end{array}$ & $\begin{array}{c}\text { 6th } \\
\text { (Jul/17) }\end{array}$ & $\begin{array}{c}\text { 7th } \\
\text { (Aug/17) }\end{array}$ & $\begin{array}{c}\text { 8th } \\
(\text { Sep/17) }\end{array}$ \\
\hline \multicolumn{9}{|l|}{ 1st cycle } \\
\hline Control & $113.0 a$ & $90.8 a$ & $84.0 a$ & $68.8 a$ & $60.4 a$ & $35.8 b$ & $32.2 a$ & $33.2 a$ \\
\hline Reference & $117.6 a$ & $92.4 a$ & $92.0 a$ & $64.0 a$ & $54.6 a$ & $54.6 a$ & $31.8 a$ & $33.0 a$ \\
\hline Recommended & $118.4 a$ & $91.0 a$ & $91.6 a$ & $69.2 a$ & $58.8 a$ & $35.8 b$ & $32.4 a$ & $33.0 \mathrm{a}$ \\
\hline NSI98\% & $115.4 a$ & $85.4 a$ & $89.2 a$ & $67.4 a$ & $59.4 a$ & $35.2 b$ & $31.0 a$ & $33.8 a$ \\
\hline NSI94\% & $112.8 a$ & 91.0a & $87.2 a$ & $68.6 a$ & $58.4 a$ & $35.4 b$ & $31.2 a$ & $31.2 a$ \\
\hline NSI90\% & 116.0a & $92.2 a$ & $89.4 a$ & $67.6 a$ & $58.0 a$ & $37.4 b$ & $34.6 a$ & $34.6 a$ \\
\hline CV (\%) & 5.35 & 5.76 & 5.77 & 6.97 & 5.97 & 7.17 & 8.83 & 6.10 \\
\hline \multicolumn{9}{|c|}{ 2nd cycle } \\
\hline & $\begin{array}{c}\text { 9th } \\
\text { (Oct/17) }\end{array}$ & $\begin{array}{c}\text { 10th } \\
\text { (Nov/17) }\end{array}$ & $\begin{array}{c}\text { 11th } \\
\text { (Dec/17) }\end{array}$ & $\begin{array}{c}\text { 12th } \\
\text { (Jan/18) }\end{array}$ & $\begin{array}{c}\text { 13th } \\
\text { (Feb/18) }\end{array}$ & $\begin{array}{c}\text { 14th } \\
\text { (Mar/18) }\end{array}$ & $\begin{array}{c}\text { 15th } \\
\text { (Apr/18) }\end{array}$ & $\begin{array}{c}\text { 16th } \\
\text { (May/18) }\end{array}$ \\
\hline Control & $37.2 a$ & $66.2 a$ & 91.8b & $89.2 \mathrm{ab}$ & $76.6 a$ & $73.2 a$ & 87.0a & $62.0 \mathrm{ab}$ \\
\hline Reference & $33.8 a$ & $63.2 a$ & $106.6 a$ & $96.4 a$ & $75.8 a$ & $74.0 a$ & $81.8 a$ & $55.6 b$ \\
\hline Recommended & 33.8a & $63.0 a$ & 104.0ab & $91.0 a b$ & $78.0 a$ & $77.0 a$ & $85.0 a$ & $59.8 a b$ \\
\hline NSI98\% & $33.2 \mathrm{a}$ & $60.0 a$ & 106.0a & 89.6ab & $75.2 a$ & $75.2 a$ & $84.0 a$ & $63.6 a$ \\
\hline NSI94\% & $33.6 a$ & $61.0 a$ & 102.6ab & $85.4 b$ & $76.2 a$ & $74.8 a$ & $81.2 a$ & $63.2 a$ \\
\hline NSI90\% & $36.6 a$ & $65.8 a$ & $94.8 a b$ & $85.0 b$ & $76.8 a$ & $76.8 a$ & $85.8 a$ & $62.2 \mathrm{ab}$ \\
\hline CV (\%) & 8.20 & 8.11 & 6.93 & 4.73 & 7.41 & 8.96 & 9.71 & 6.10 \\
\hline
\end{tabular}

Common letters in the column do not differ by Tukey's test at $5 \%$ probability.

$\mathrm{NSI}$ - nitrogen sufficiency index; CV - coefficient of variation.

Nitrogen fertilization management did not influence the initial development of mombaça grass tillers, since there was no difference in any of the evaluated periods, in the first cycle (Table 3). Leite et al. (2019) also did not observe increase in tillering as a function of $\mathrm{N}$ doses, after three cutsharvests, in plants not inoculated with Azospirilum brasilense, with a mean value of 296 tillers $\mathrm{m}^{-2}$, a value well below those observed in the experiment. 
Table 3

Tiller density (tillers $\mathrm{m}^{-2}$ ) of mombaça grass at five harvests in the first cycle as a function of nitrogen fertilization, based on the chlorophyll meter

\begin{tabular}{cccccc} 
& \multicolumn{5}{c}{ Harvest } \\
\cline { 2 - 6 } Treatment & 1st (Feb/17) & 2nd (Mar/17) & 3rd (Apr/17) & 4th (May/17) & 5th (Jun/17) \\
Control & $617 a$ & $790 a$ & $1,046 a$ & $1,117 a$ & $826 a$ \\
Reference & $596 a$ & $754 a$ & $2,538 a$ & $1,043 a$ & $758 a$ \\
Recommended & $675 a$ & $731 a$ & $925 a$ & $982 a$ & $752 a$ \\
NSI98\% & $722 a$ & $793 a$ & $954 a$ & $1,117 a$ & $822 a$ \\
NSI94\% & $674 a$ & $795 a$ & $870 a$ & $1,027 a$ & $806 a$ \\
NSI90\% & $672 a$ & $781 a$ & $896 a$ & $1,066 a$ & $768 a$ \\
CV (\%) & 9.63 & 10.76 & 12.50 & 7.37 & 10.02
\end{tabular}

Common letters in the column do not differ by Tukey's test at $5 \%$ probability. $\mathrm{NSI}$ - nitrogen sufficiency index; CV - coefficient of variation.

In the second cycle, it was possible to observe the influence of the use of fertilization (Table 4). At the 7th harvest, the reference treatment provided a higher tiller density, with 858 tillers $\mathrm{m}^{-2}$, representing a $22 \%$ larger population than in control treatment, though statistically equal to those calculated in NSI94\% and NSI98\%. At the 8th harvest, the highest number of tillers was found in the NSI98\% treatment, which differed only from NSI90\%. At the 11th harvest, the NSI94\%, $\mathrm{NSI98 \%}$, and recommended treatments showed the best results, and at the 12th evaluation, there was an equivalence between the treatments, with a lower number of tillers found only in the reference treatment.

Table 4

Tiller density (tillers $\mathrm{m}^{-2}$ ) of mombaça grass at seven harvests in the second cycle as a function of nitrogen fertilization, based on the chlorophyll meter, in the years 2017 and 2018

\begin{tabular}{|c|c|c|c|c|c|c|c|}
\hline \multirow[b]{2}{*}{ Treatment } & \multicolumn{7}{|c|}{ Harvest } \\
\hline & $\begin{array}{l}\text { 6th } \\
\text { (Nov) }\end{array}$ & $\begin{array}{l}\text { 7th } \\
\text { (Dec) }\end{array}$ & $\begin{array}{l}\text { 8th } \\
\text { (Jan) }\end{array}$ & $\begin{array}{c}\text { 9th } \\
\text { (Feb) }\end{array}$ & $\begin{array}{l}\text { 10th } \\
\text { (Mar) }\end{array}$ & $\begin{array}{l}\text { 11th } \\
\text { (Apr) }\end{array}$ & $\begin{array}{c}\text { 12th } \\
\text { (May) }\end{array}$ \\
\hline Control & $749 a$ & $704 b$ & $982 a b$ & $800 a$ & $787 a$ & $864 b c$ & $784 a$ \\
\hline Reference & $902 a$ & $858 a$ & $995 a b$ & $832 a$ & $803 a$ & $813 c$ & $608 b$ \\
\hline Recommended & $816 a$ & 768ab & $896 a b$ & $838 a$ & $845 a$ & $912 a b c$ & $723 a b$ \\
\hline NSI98\% & $874 a$ & $800 a b$ & $1,024 a$ & $813 a$ & $918 a$ & $992 a b$ & $790 a$ \\
\hline NSI94\% & $784 a$ & $816 a b$ & $966 a b$ & $886 a$ & $877 a$ & $1,056 a$ & $845 a$ \\
\hline NSI90\% & $848 a$ & $714 b$ & $838 b$ & $794 a$ & $803 a$ & $758 c$ & $832 a$ \\
\hline CV (\%) & 9.54 & 7.69 & 8.93 & 10.69 & 9.76 & 9.49 & 10.69 \\
\hline
\end{tabular}

Common letters in the column do not differ by Tukey's test at $5 \%$ probability.

$\mathrm{NSI}$ - nitrogen sufficiency index; CV - coefficient of variation. 
At the 1st harvest, the largest DB accumulation was observed in the reference treatment. Control showed the lowest yield, and the other treatments did not differ from each other (Table 5).

\section{Table 5}

Accumulated dry biomass ( $\left.\mathrm{kg} \mathrm{ha}^{-1}\right)$ of mombaça grass at the first five harvests as a function of nitrogen fertilization, based on the chlorophyll meter, in the years 2017 and 2018

\begin{tabular}{cccccc} 
Treatment & \multicolumn{5}{c}{ Harvest } \\
\cline { 2 - 6 } Control & 1st (Feb) & 2nd (Mar) & 3rd (Apr) & 4th (May) & 5th (Jun) \\
Reference & $3,541 \mathrm{c}$ & $2,335 \mathrm{bc}$ & $2,414 \mathrm{c}$ & $139 \mathrm{~b}$ & $323 \mathrm{~b}$ \\
Recommended & $4,445 \mathrm{a}$ & $2,590 \mathrm{ab}$ & $2,646 \mathrm{bc}$ & $1,436 \mathrm{a}$ & $427 \mathrm{ab}$ \\
NSI98\% & $3,842 \mathrm{~b}$ & $2,788 \mathrm{a}$ & $2,677 \mathrm{abc}$ & $1,393 \mathrm{a}$ & $545 \mathrm{a}$ \\
NSI94\% & $3,993 \mathrm{~b}$ & $2,436 \mathrm{bc}$ & $2,812 \mathrm{ab}$ & $1,410 \mathrm{a}$ & $558 \mathrm{a}$ \\
NSI90\% & $3,939 \mathrm{~b}$ & $2,183 \mathrm{c}$ & $2,412 \mathrm{c}$ & $1,285 \mathrm{a}$ & $400 \mathrm{~b}$ \\
CV (\%) & $4,110 \mathrm{~b}$ & $2,305 \mathrm{c}$ & $2,939 \mathrm{a}$ & $1,324 \mathrm{a}$ & $561 \mathrm{a}$ \\
& 3.65 & 5.59 & 5.50 & 17.10 & 14.72
\end{tabular}

Common letters in the column do not differ by Tukey's test at $5 \%$ probability.

$\mathrm{NSI}$ - nitrogen sufficiency index; CV - coefficient of variation.

At the 2 nd harvest, the recommended treatment showed the highest DB yield, although it did not differ from the reference treatment. At the 3rd harvest, the calculated index of $90 \%$ provided better results, followed by the NSI98\% and recommended treatments. At the 4th harvest, only control treatment showed a lower yield and, at the 5 th evaluation, besides control, the reference treatment also provided lower values: 323 and $400 \mathrm{~kg}$ $\mathrm{ha}^{-1}$, respectively. Although large increases in $\mathrm{BD}$ accumulation were not observed due to nitrogen fertilization, in this first cycle, Mombaça grass may show an increase in BD accumulation due to organic fertilization in the planting and topdressing mineral fertilization (50 kg ha-1 $\mathrm{N}$ after each harvest), in the first four cropsharvests (Guerrero, Sousa, Oliveira, Caldeira, \& Pelá, 2020).

In the second cycle, there was no difference between treatments only in January, corresponding to the 8th harvest (Table 6). At the 6th harvest the first of the second cycle, the highest yield was obtained in the recommended treatment; however, it did not differ from that obtained at the calculated index of $90 \%$. 


\section{Table 6}

Dry biomass (kg ha-1) of mombaça grass at seven harvests in the second cycle as a function of nitrogen fertilization, based on the chlorophyll meter, in the years 2017 and 2018

\begin{tabular}{cccccccc} 
& \multicolumn{7}{c}{ Harvest } \\
\cline { 2 - 7 } Treatment & $\begin{array}{c}\text { 6th } \\
\text { (Nov) }\end{array}$ & $\begin{array}{c}\text { 7th } \\
\text { (Dec) }\end{array}$ & $\begin{array}{c}\text { 8th } \\
\text { (Jan) }\end{array}$ & $\begin{array}{c}9 \text { th } \\
(\text { Feb) }\end{array}$ & $\begin{array}{c}10 \text { th } \\
\text { (Mar) }\end{array}$ & $\begin{array}{c}11 \text { th } \\
\text { (Apr) }\end{array}$ & $\begin{array}{c}12 \text { th } \\
\text { (May) }\end{array}$ \\
Control & $1,088 \mathrm{c}$ & $1,470 \mathrm{c}$ & $2,076 \mathrm{a}$ & $2,174 \mathrm{~d}$ & $1,764 \mathrm{bc}$ & $2,639 \mathrm{~d}$ & $1,106 \mathrm{c}$ \\
Reference & $1,26 \mathrm{bc}$ & $3,081 \mathrm{a}$ & $2,461 \mathrm{a}$ & $2,403 \mathrm{c}$ & $1,706 \mathrm{c}$ & $2,785 \mathrm{~cd}$ & $1,123 \mathrm{c}$ \\
Recommended & $1,536 \mathrm{a}$ & $2,485 \mathrm{~b}$ & $2,271 \mathrm{a}$ & $2,654 \mathrm{ab}$ & $2,201 \mathrm{a}$ & $3,059 \mathrm{~b}$ & $1,427 \mathrm{~b}$ \\
NSI98\% & $1,268 \mathrm{bc}$ & $2,309 \mathrm{~b}$ & $2,308 \mathrm{a}$ & $2,474 \mathrm{bc}$ & $2,094 \mathrm{a}$ & $3,742 \mathrm{a}$ & $1,632 \mathrm{a}$ \\
NSI94\% & $1,124 \mathrm{c}$ & $3,085 \mathrm{a}$ & $2,089 \mathrm{a}$ & $2,689 \mathrm{a}$ & $2,047 \mathrm{a}$ & $3,507 \mathrm{a}$ & $1,486 \mathrm{ab}$ \\
NSI90\% & $1,435 \mathrm{ab}$ & $2,522 \mathrm{~b}$ & $2,076 \mathrm{a}$ & $2,137 \mathrm{~d}$ & $2,017 \mathrm{ab}$ & $2,979 \mathrm{bc}$ & $1,526 \mathrm{ab}$ \\
CV (\%) & 7.08 & 4.42 & 8.94 & 4.13 & 6.50 & 4.26 & 6.52
\end{tabular}

Common letters in the column do not differ by Tukey's test at $5 \%$ probability. $\mathrm{NSI}$ - nitrogen sufficiency index; CV - coefficient of variation.

At the 7th harvest, the recommended and NSI94\% treatments showed the highest yields (3081 and $3085 \mathrm{~kg} \mathrm{ha}^{-1}$, respectively), and these two treatments were also the most productive at the 9 th harvest. At the 10th harvest, the calculated indices of $94 \%$ and $98 \%$ showed similar results to the recommended treatment, and these did not differ from the NSI90\% treatment. At the 11th and 12th harvests, the calculated indices exhibited greater efficiency, especially 94\% and $98 \%$, resulting in the highest DB yields.

Considering the accumulated yield (Table 7), in the first cycle, control treatment provided the least DB, followed by NSI94\%, and the other treatments did not differ from each other. In the second cycle, the recommended, NSI98\%, and NSI94\% treatments provided the highest the highest yield. Between the two cycles, higher DB yield means were obtained in the second. Salman et al. (2016), evaluating the use of NSI of $0.96,0.93,0.90,0.87$, and 0.83 in the management of nitrogen fertilization of Marandu and Mombaça grasses, in two cuts, concluded that the lowest indices were the most suitable because they provided greater dry matter with a lower dose of $\mathrm{N}$.

Considering the amount of DB produced per kilogram of $\mathrm{N}$ applied in fertilization (agronomic efficiency), in the first cycle, the NSI90\% treatment was more efficient (49.94 $\mathrm{kg}$ DB per $\mathrm{kg} \mathrm{N}$ applied) than the other treatments with fertilization based on NSI, which, in turn, provided greater efficiency in the use of $\mathrm{N}$ in fertilization than the reference and recommended treatments. As in the first cycle, the NSI90\% treatment was also superior to the others in the second cycle, producing $47.52 \mathrm{~kg} \mathrm{DB} \mathrm{kg} \mathrm{N}^{-1}$. The use of a chlorophyll meter and the NSI, in the management of nitrogen fertilization, in brachiaria grass pasture, also allowed for greater efficiency in the use of nitrogen (Villar, Pinto, Fonseca, Queiroz \& Alcântara, 2015). 


\section{Table 7}

Accumulated dry biomass (DB) of mombaça grass as a function of nitrogen fertilization, based on the chlorophyll meter, in the two cycles evaluated, in the years 2017 and 2018

\begin{tabular}{|c|c|c|c|c|}
\hline Treatment & $\begin{array}{l}\text { Dry biomass } \\
\text { accumulated in the } \\
\text { first cycle }(\mathrm{kg})\end{array}$ & $\begin{array}{l}\text { Agronomic } \\
\text { efficiency } \\
\left(\mathrm{kg} \mathrm{DB} \mathrm{kg} \mathrm{N}^{-1}\right)\end{array}$ & $\begin{array}{l}\text { Dry biomass } \\
\text { accumulated in the } \\
\text { second cycle (kg) }\end{array}$ & $\begin{array}{l}\text { Agronomic } \\
\text { efficiency } \\
\left(\mathrm{kg} \mathrm{DB} \mathrm{kg} \mathrm{N}^{-1}\right)\end{array}$ \\
\hline Control & $8,752 c B$ & - & $12,318 d A$ & - \\
\hline Reference & $11,545 \mathrm{aB}$ & 3.10 & $14,897 \mathrm{bcA}$ & 2.46 \\
\hline Recommended & $11,246 a B$ & 8.31 & $15,454 a b A$ & 4.82 \\
\hline NSI98\% & $11,209 a B$ & 24.57 & $15,827 a A$ & 8.77 \\
\hline NSI94\% & $10,219 b B$ & 29.34 & $16,028 \mathrm{aA}$ & 12.37 \\
\hline NSI90\% & $11,249 a B$ & 49.94 & $14,694 \mathrm{cA}$ & 47.52 \\
\hline Mean & 10,703 & & 14,888 & \\
\hline
\end{tabular}

Common lowercase letters in the column and uppercase letters in the row do not differ by Tukey's test at $5 \%$ probability. $\mathrm{NSI}$ - nitrogen sufficiency index.

Forage height is a significant trait for management, as it influences the intake of grazing animals. However, it should not be evaluated in isolation. In the first cycle of the experiment, no difference was detected between the treatments for this variable, but control treatment, which did not receive $\mathrm{N}$, produced $8,16,10,90$, and $41 \%$ less DB than the recommended treatment, at the five harvests. Although plant height can ensure a satisfactory leaf mass yield, stem elongation can negatively influence the nutritive value of the grass and grazing efficiency (Ribeiro et al., 2012; V. H. M. Macedo et al., 2017), as a result of the higher leaf:stem ratio.

In some periods evaluated in this experiment, mombaça grass did not reach the preset harvest height due to climatic conditions. The grass was not able to maintain its development due to the absence of soil solution that could allow the development of the plant. Pereira et al. (2011) also observed seasonality in mombaça grass during the dry period of the year.
The tiller constitutes the pastureforming unit. Thus, its production volume, ground cover capacity, and pasture formation potential are essential factors for its proper management and longevity (Faria et al., 2015). In the first year of the experiment, no treatment effect was observed, with tiller density reaching an average of $789 \mathrm{~m}^{-2}$ at the end of the cycle. In the second cycle, the importance of $\mathrm{N}$ for the tillering of mombaça grass was observed.

At the 8th harvest, the NSI98\% treatment stood out with a higher number of tillers. The same was observed for the 11th and 12th harvests, whose result equaled that of the recommended treatment, which suggests that smaller amounts of $\mathrm{N}$ can be applied by adopting this methodology, saving on $\mathrm{N}$ fertilization.

At the 11th harvest, the number of tillers in the NSI94\% treatment was 22 and $39 \%$ higher than those obtained in the control (without fertilization) and NSI90\% treatments, respectively, which had received $50 \mathrm{~kg} \mathrm{ha}^{-1}$ of 
$\mathrm{N}$ thus far. The NSI94\% treatment had received the $\mathrm{N}$ dose of $250 \mathrm{~kg} \mathrm{ha}^{-1}$, vs. the 1,650, 550, and $350 \mathrm{~kg} \mathrm{ha}^{-1} \mathrm{~N}$ applied in the reference, recommended, and NSI98\% treatments, respectively.

The last evaluation took place in May, when lower temperatures and precipitation occurred and an equivalence was observed between the treatments. A smaller number of tillers was only seen in the reference treatment, possibly due to the excess $\mathrm{N}$ applied.

Other studies demonstrate the importance of $\mathrm{N}$ in the tillering of forages. Pereira et al. (2011) worked with mombaça grass and described that $\mathrm{N}$ applications of $320 \mathrm{~kg} \mathrm{ha}^{-1}$, in relation to no $\mathrm{N}$ fertilization, provided an average increase of $107 \%$ in the total number of tillers in the summer.

However, Martuscello et al. (2015), evaluating Capim-Massai at different nitrogen rates, show the highest number of tillers at $160 \mathrm{~kg} \mathrm{ha}^{-1}$ of $\mathrm{N}$, until the fourth generation, and from then on, the largest number of tillers found was by the treatment with absence of fertilization. And they attribute this behavior to the fact that fertilized plants tend to increase the deposition of dry mass, which promotes greater shading and, consequently, a smaller number of tillers, since light also acts as a tillering inducer.Therefore, in addition to the amount used, soil-climatic conditions are limiting for the development of forage.

Unlike plant height and tiller density, DB yield was influenced by the treatments already at the 1 st harvest. The lower yield obtained in control treatment reflects the initial fertilization of the experiment, since this treatment did not receive $\mathrm{N}$ fertilization, whereas the reference treatment received $150 \mathrm{~kg} \mathrm{ha}^{-1}$ of $\mathrm{N}$ and, the others, $50 \mathrm{~kg} \mathrm{ha}^{-1}$.
Pietroski, Oliveira and Caione (2015) worked with $\mathrm{N}$ fertilization in mombaça grass and observed a higher DB yield using the $\mathrm{N}$ dose of $35 \mathrm{~kg} \mathrm{ha}^{-1}(1,799 \mathrm{~kg}$ DB ha-1) at the $1 \mathrm{st}$ harvest, whereas the treatment that did not receive fertilization resulted in a DB yield of 830 $\mathrm{kg} \mathrm{ha}^{-1}$. The increase in forage yield following the application of $\mathrm{N}$ doses is attributed to the importance of this nutrient for different morphological traits (Martuscello et al., 2019).

At the 2nd harvest, the recommended treatment was the only one that provided a higher DB yield than control, despite the fact that it received a lower dose of $\mathrm{N}$ than the reference treatment. This is related to the regrowth potential of the forage, which produced a greater amount of DB at the 1st harvest, but equaled the treatment with the lowest fertilizer dose at the 2nd harvest. However, at the other harvests (3rd, 4th, and 5th), "recommended" remained among the most productive treatments.

From the 1st to the 3rd harvest, the treatments that received the highest $\mathrm{N}$ doses were reference and recommended: 450 and $150 \mathrm{~kg} \mathrm{ha}^{-1}$, respectively (Table 1). These provided the highest DB yields at the first two harvests, demonstrating the importance of $\mathrm{N}$ for the initial impulse of the forage. Salman et al. (2016) used NSI of $96,93,90,87$, and $83 \%$ to determine $\mathrm{N}$ fertilization for marandu and mombaça grasses and observed that, for the former, DB production differed significantly between the reference (133 $\mathrm{kg} \mathrm{ha}^{-1} \mathrm{~N}$ ) and control treatments at the 2 nd harvest, due to the higher amount of the nutrient applied in relation to the others.

Unlike what was obtained in this experiment, Factori et al. (2017) found no difference in response to the $\mathrm{N}$ doses of 0 , 
50, 100, and $200 \mathrm{~kg} \mathrm{ha}^{-1}$ at the first three harvests, whereas significant differences were described at the others (4th, 5th, and 6th harvests). Therefore, the DByield may be due to the environmental effect and the management for the establishment of the forage.

The lowest yield mean obtained in the treatment that did not receive $\mathrm{N}$ fertilization, at the 4th harvest, indicates the depletion of the $\mathrm{N}$ available in the soil for the grass. In control, DB yield was, on average, ten times lower than that obtained in the other treatments, which received at least $50 \mathrm{~kg} \mathrm{ha}^{-1} \mathrm{~N}$, highlighting the importance of this base $\mathrm{N}$ fertilization. Nitrogen fertilization considerably increases forage DB yield (Benett, Buzetti, Silva, Bergamaschine, \& Fabricio, 2008; Mazza et al., 2009; Galindo et al., 2017), which confirms the low production obtained by the treatment without $\mathrm{N}$.

Besides the lack of $\mathrm{N}$, the application of excessive doses can also be detrimental, given the smaller amount of biomass produced in the reference treatment, at the 5th evaluation. At that evaluation, there was also a reduction in yield due to the extraordinary low temperature condition in the region (Figure 1).

The data referring to the second cycle demonstrate the efficiency of the indices used, since the first cut. During the first cycle, the recommended treatment, fertilized with $300 \mathrm{~kg}$ ha- 1 of N, which was split into six equal applications, expressed the highest yield. However, it did not differ from the NSI90\% treatment, which received $50 \mathrm{~kg} \mathrm{ha}^{-1}$ of $\mathrm{N}$ a base fertilization.

At the other harvests, the $94 \%$ and $98 \%$ indices were even superior in yield when compared with the reference and recommended treatments, which received higher amounts of N. The use of NSI90\% or
NSI95\% in the common-bean crop provided rationalized use of N (Maia, Soratto, Biazotto and Almeida, 2013; Silveira \& Ferreira, 2016; Silveira \& Gonzaga, 2017).

At the last two harvests in the second cycle, the control and reference treatments showed lower yields, due to deficiency and excess of $\mathrm{N}$, respectively. The recommended treatment produced less DB than NSI98\%, which may also be an indicator of excess $\mathrm{N}$, since, in total, it received an additional $250 \mathrm{~kg}$ ha- 1 when compared with the calculated index of $98 \%$.

At the end of the first cycle, the reference, recommended, and NSI98\% treatments received a total of 900,300 , and $100 \mathrm{~kg} \mathrm{ha}^{-1}$ of N, respectively. The NSI94 and $\mathrm{NSI90 \%}$ treatments received $50 \mathrm{~kg} \mathrm{ha}^{-1}$ of $\mathrm{N}$ (only at base fertilization, in January 2017), and control did not receive $\mathrm{N}$ fertilization. By the end of the second cycle, the plots of the reference, recommended, NSI98\%, NSI94\%, and NSI90\% treatments had received 1,050, $350,300,250$, and $0 \mathrm{~kg} \mathrm{ha}^{-1}$ of $\mathrm{N}$, respectively (Table 1). Therefore, the use of $\mathrm{N}$ fertilization resulted in a positive increase in the DB yield of Mombaça grass, with the application of 50 to $900 \mathrm{~kg} \mathrm{ha}^{-1}$ of $\mathrm{N}$, in the first cycle and 250 to $350 \mathrm{~kg} \mathrm{ha}^{-1}$ in the second production cycle. Accordingly, it appears that, to achieve greater yields, $\mathrm{N}$ utilization decreased with the production cycles.

Rosado, Gontijo, Almeida and Andrade (2014) also used urea as a source of $\mathrm{N}$ and found a reduction in soil $\mathrm{pH}$ and $\mathrm{P}$ content as well as an increase in potential acidity following the application of the $\mathrm{N}$ dose of $600 \mathrm{~kg} \mathrm{ha}^{-1}$, which can impair the development of forage. However, efficiency in nitrogen fertilization is sought, since the application of $\mathrm{N}$ above the 
responsiveness of grass, in addition to not providing increases in production, not differing from the doses considered ideal, can lead to a decrease in productivity and, consequently, economic losses to the system (Patzlaff, Zulpo, \& Rossi, 2020; Castagnara et al., 2011)

Therefore, the use of doses that exceed the forage response potential leads to waste of fertilizer and, consequently, economic losses to the system, in addition to potential environmental losses caused by nitrate leaching (Rambo, Silva, Argenta, \& Bayer 2004). According to Ryan et al. (2011), animal nutrition is related to rational management of $\mathrm{N}$ for forage production, which can reduce the environmental and financial impact.

The highest average DB yield obtained in the second cycle coincides with the period of greatest response of the grass, as it is already established, whereas in the first cycle, the grass is still in the process of formation and development of its morphogenetic traits and the number of clumps in the pasture not yet stabilized, many empty spaces and different clump sizes (Pereira et al., 2011).

Using NSI98\% as a parameter made it possible to reduce and rationally use the $\mathrm{N}$ fertilizer, as it provided the same DB yield as the recommended treatment, in both cycles, using $250 \mathrm{~kg} \mathrm{ha}^{-1}$ less $\mathrm{N}$.

The use of NSI90\% to define the need for $\mathrm{N}$ fertilization provided the same DB yield in mombaça grass as the recommended treatment, in the first cycle. Nevertheless, in the second cycle, yield was lower. However, the $\mathrm{N}$ dose applied was only $50 \mathrm{~kg} \mathrm{ha}^{-1}$, which was $600 \mathrm{~kg}$ less than that used in the recommended treatment, resulting in greater agronomic efficiency with the use of NSI90\%.
The use of the chlorophyll meter to estimate the plant nutritional status in terms of $\mathrm{N}$ was tested by Ali, Thind, Sharma and Singh (2015) in the rice crop and by Padilla, PeñaFleitas, Gallardo and Thompson (2015) in tomato. Both attested to the superiority of this method over the common recommendation, in advising the management of $\mathrm{N}$ fertilization. In pasture crop, Pariz et al. (2011) found that the chlorophyll content can be used to estimate DM production, crude protein density, as well as the need for $\mathrm{N}$ fertilization in Panicum maximum cv. Tanzania and Mombaça.

Factori et al. (2017) tested the response of mombaça grass to $\mathrm{N}$ doses of 100 to 400 $\mathrm{kg} \mathrm{ha}^{-1}$ in an irrigated system and observed maximum response at the $\mathrm{N}$ dose of $300 \mathrm{~kg}$ $\mathrm{ha}^{-1}$, with a yield of $13 \mathrm{tha}^{-1}$. Therefore, since the present experiment was carried out in a rainfed system and similar yields were achieved, the response to equivalent fertilization at the $\mathrm{N}$ doses of 250 and $1,050 \mathrm{~kg} \mathrm{ha}^{-1}$ is justified, as the availability of soil solution is a limiting factor in this system, which impairs the agronomic potential of Panicum maximum cv. Mombaça.

Esta seção deve ser apresentada de forma clara, com o auxílio de tabelas, gráficos e figuras, de forma que não suscite dúvidas ao leitor quanto à autenticidade dos resultados e pontos de vista discutidos.

\section{Conclusions}

In mombaça grass, the nitrogen fertilization management based on the $90 \%$ nitrogen sufficiency index, obtained using the chlorophyll meter, provided the greatest agronomic efficiency.

The use of the $98 \%$ nitrogen sufficiency index in the fertilization management provided 
the same dry biomass yield in mombaça grass as the recommended fertilization strategy, except with five applications of $50 \mathrm{~kg} \mathrm{ha}^{-1}$ less nitrogen.

\section{References}

Ali, M., Thind, H. S., Sharma, S., \& Singh, Y. (2015). Site-Specific nitrogen management in dry direct-seeded rice using chlorophyll meter and leaf colour chart. Pedosphere, 25(1), 72-81. doi: 10.1016/S1002-0160 (14)60077-1

Alvares, C. A., Stape, J. L., Sentelhas, P. C., Gonçalves, J. L. M., \& Sparovek, G. (2013). Köppen's climate classification map for Brazil. Meteorologische Zeitschrift, 22(6), 711-728. doi: 10.1127/0941-2948/2013/ 0507

Benett, C. G. S., Buzetti, S., Silva, K. S., Bergamaschine, A. F., \& Fabricio, J. A. (2008). Produtividade e composição bromatológica do capim-marandu a fontes e doses de nitrogênio. Ciência e Agrotecnologia, 32(5), 1629-1636. doi: 10.1590/S1413-70542008000500041

Brâncio, P. A., Nascimento, D., Jr., Euclides, V. P. B., Fonseca, D. M., Almeida, R. G., Macedo, M. C. M., \& Barbosa, R. A. (2003). Avaliação de três cultivares de Panicum maximum Jacq. sob pastejo: composição da dieta, consumo de matéria seca e ganho de peso animal. Revista Brasileira de Zootecnia, 32(5), 1037-1044. doi: 10.1590/S1516-35982003000500002

Canto, M. W., Barth, A. Neto, Pancera, E. J. Jr., Gasparino, E., \& Boleta, V. S. (2012). Produção e qualidade de sementes do capim-Mombaça em função da adubação nitrogenada. Bragantia, 71(3), 430-
437. doi: 10.1590/S0006-8705201200 5000032

Castagnara, D. D., Zoz, T., Krutzmann, A., Uhlein, A., Mesquita, E. E., Neres, M. A., \& Oliveira, P. S. R. (2011). Produção de forragem, características estruturais e eficiência de utilização do nitrogênio em forrageiras tropicais sob adubação nitrogenada. Semina: Ciências Agrárias, 32(4), 1637-1648. doi: 10.5433/16790359.2011v32n4p1637

Empresa Brasileira de Pesquisa Agropecuária (1997). Manual de métodos de análise de solo (2a ed.). Rio de Janeiro, RJ: EMBRAPA.

Empresa Brasileira de Pesquisa Agropecuária (2018). Sistema brasileiro de classificação de solos (3a ed.). Rio de Janeiro, RJ: EMBRAPA.

Factori, M. A., Silva, P. C. G., Gonçalves, D. M., Scatulin, A. S. N., Neto, Maratti, C. H. Z., \& Tiritan, C. S. (2017). Produtividade de massa de forragem e proteína bruta do capim Mombaça irrigado em função da adubação nitrogenada. Colloquium Agrariae, 13(3), 49-57. doi: 10.5747/ca. 2017.v13.n3.a173

Fageria, N. K., Slaton, N. A., \& Baligar, V. C. (2003). Nutrient management for improving lowland rice productivity and sustainability. Advances in Agronomy, 80, 63-152. doi: 10.1016/S0065-2113 (03)80003-2

Fagundes, J. L., Moreira, A. L., Freitas, A. W. P., Zonta, A., Henrichs, R., Rocha, F. C.,... Vieira, J. S. (2011). Capacidade de suporte de pastagens de capim-tifton 85 adubado com nitrogênio manejadas em lotação contínua com ovinos. Revista Brasileira de Zootecnia, 40(12), 2651-2657. doi: 10.1590/S1516-35982011001200006 
Faria, A. J. G., Freitas, G. A., Georgetti, A. C. P., Ferreira, J. M., Jr., Silva, M. C. A., \& Silva, R. R. (2015). Adubação nitrogenada e potássica na produtividade do capim Mombaça sobre adubação fosfatada. Journal of Bioenergy and Food Science, 2(3), 98-106. doi: 10.18067/jbfs.v2i3.24

Ferreira, D. F. (2014). Sisvar: a guide for its bootstrap procedures in multiple comparisons. Ciência e Agrotecnologia, 38(2), 109-112. doi: 10.1590/S1413-7054 2014000200001

Galindo, F. S., Buzetti, S., Teixeira, M. C. M., Fo., Dupas, E., \& Ludkiewicz, M. G. Z. (2017). Application of different nitrogen doses to increase nitrogen efficiency in Mombasa guinegrass (Panicum maximum cv. mombasa) at dry and rainy seasons. Australian Journal of Crop Science, 11(12), 1657-1664. doi: 10.21475/ajcs.17.11.12. pne907

Garcia, C. S., Fernandes, A. M., Fontes, C. A. A., Vieira, R. A. M., Sant'Ana, N. F., \& Pimentel, A. V. A. (2011). Desempenho de novilhos mantidos em pastagens de capimelefante e capim-Mombaça. Revista Brasileira Zootecnia, 40(2), 403-410. doi: 10.1590/S1516-35982011000200023

Guerrero, M. C., Sousa, T. R., Oliveira, S. A., Caldeira, R. R., \& Pelá, A. (2020) Productivity and quality of Mombasa grass under fertilization with pig deeplitter and NPK. Revista Brasileira de Engenharia Agrícola e Ambiental, 24(7), 437-443. doi: 10.1590/1807-1929/ agriambi.v24n7p437-443

Hanrahan, L., Mchugh, N., Henessy, T., Moran, B., Kearney, R., Wallace, M., \& Shallo, L. (2018). Factors associated with profitability in pasture-based systems of milk prodution.
Journal of Dairy Science, 101(6), 54746585. doi: 10.3168/jds.2017-13223

Leite, R. C., Santos, A. C., Santos, J. G. D., Leite, R. C., Oliveira, L. B. T., \& Hungria, M. (2019). Mitigation of mombasa grass (Megathysus maximus) dependence on nitrogen fertilization as a function of inoculation with Azospirillum brasilense. Revista Brasileira de Ciência do Solo, 43, 1-14. doi: 10.1590/18069657rbcs20180234

Macedo, C. H. O., Andrade, A. P., Santos, E. M., Silva, D. S., Silva, T. C., \& Edvan, R. L. (2012). Perfil fermentativo e composição bromatológica de silagens de sorgo em função da adubação nitrogenada. Revista Brasileira de Saúde e Produção Animal, 13(2), 371-382. doi: 10.1590/S1519-9940 2012000200007

Macedo, V. H. M., Cunha, A. M. Q., Candido, E. P., Domingues, F. N., Melo, D. M., \& Rego, A. C. (2017). Estrutura e produtividade de capim - tanzânia submetido a diferentes frequências de desfolhação. Ciência Animal Brasileira, 18(1), 1-10. doi: 10.15 90/1089-6891v18e-38984

Maia, S. C. M., Soratto, R. P., Biazotto, F. O., \& Almeida, A. Q. (2013). Estimativa da necessidade de nitrogênio em cobertura no feijoeiro IAC Alvorada com cloforilômetro portátil. Semina: Ciências Agrárias, 34(5), 2229-2238. doi: 10.5433/1679-0359.2013v34n5p2229

Martuscello, J. A., Rios, J., Ferreira, M., Assis, J., Braz, T., \& Cunha, D. (2019). Produção e morfogênese de capim BRS Tamani sob diferentes doses de nitrogênio e intensidades de desfolhação. Boletim de Indústria Animal, 76, 1-10. doi: 10.17523/ bia.2019.v76.e1441 
Martuscello, J. A., Silva, L. P. da, Cunha, D. N. F. V. da, Batista, A. C. S., Braz, T. G. dos S., \& Ferreira, P. S. (2015). Adubação nitrogenada em capim-massai: morfogênese e produção. Ciência Animal Brasileira, 16(1), 1-13. doi: 10.1590/1089$68916 \mathrm{i} 118730$

Mazza, L. M., Pôggere, G. C., Ferraro, F.P., Ribeiro, C. B., Cherobim, V. F., Motta, A. C. V., \& Moraes, A. (2009). Adubação nitrogenada na produtividade e composição química do capim-Mombaça no primeiro planalto paranaense. Scientia Agraria, 10(4), 257265. doi: 10.5380/rsa.v10i4.14915

Padilla, F. M., Peña-Fleitas, M. T., Gallardo, M., \& Thompson, R. B. (2015). Threshold values of canopy reflectance indices and chlorophyll meter readings for optimal nitrogen nutrition of tomato. Annalsof Applied Biology, 166(2), 271-285. doi: 10. 1111/aab.12181

Pariz, C. M., Andreotti, M., Bergamaschine, A. F., Buzetti, S., Costa, N. R., Cavallini, M. C.,... Luiggi, F. G. (2011). Yield, chemical composition and chlorophyll relative content of Tanzania and Mombaça grasses irrigated and fertilized with nitrogen after corn intercropping. Revista Brasileira de Zootecnia, 40(4), 728-738. doi: 10.1590/ S1516-35982011000400005

Patzlaff, N. L., Zulpo, A. P., \& Rossi, D. S. (2020). A importância do uso da dose correta na adubação nitrogenada de tifton 85 . Revista Científica Rural, 22(2), 1-12. doi: 10.30945/rcr-v22i2.3256

Pereira, V. V., Fonseca, D. M., Martuscello, J. A., Braz, T. G. S., Santos, M. V., \& Cecon, P. R. (2011). Características morfogênicas estruturais de capim-Mombaça em três densidades de cultivo adubado com nitrogênio. Revista Brasileira de Zootecnia, 40(12), 1681-2689. doi: 10.1590/S151635982011001200010

Pietroski, M., Oliveira, R., \& Caione, G. (2015). Adubação foliar de nitrogênio em capim Mombaça (Panicum maximum cv. Mombaça). Journal of Neotropical Agriculture, 2(3), 49-53. doi: 10.32404/ rean.v2i3.684

Rambo, L., Silva, P. R. F., Argenta, G., \& Bayer, C. (2004). Testes de nitrato no solo como indicadores complementares no manejo da adubação nitrogenada em milho. Ciência Rural, 34(4), 1279-1287. doi: 10.1590/S0103-84782004000400054

Ribeiro, A. M., Oliveira, M. E., Silva, P. C., Rufino, M. O. A., Rodrigues, M. M., \& Santos, M. S. (2012). Canopy characteristics, animal behavior and forage intake by goats grazing on Tanzania-grass pasture with different heights. ActaScientiarum. Animal Sciences, 34(4), 371-378. doi: 10.4025/ actascianimsci.v34i4.14544

Rosado, T. L., Gontijo, I., Almeida, M. S., \& Andrade, F. V. (2014). Fontes e doses de nitrogênio e alterações nos atributos químicos de um latossolo cultivado com capim-mombaça. Revista Brasileira de Ciência do Solo, 38(3), 840-849. doi: 10.1590/S0100-06832014000300015

Ryan, W., Hennessy, D., Murphy, J. J., Boland, T. M., \& Shaloo, L. (2011). A modelo of nitrogen efficiency in contrasting grassbased dairy systems. Journal of Dairy Science, 94(2), 1032-1044. doi: 10.3168/ jds.2010-3294 
Salman, A. K. D., Bacelar, B. M. F. S., Alves, E. A., Cruz, P. G., Mendes, A. M., \& Carvalho, G. A. (2016). Uso do clorofilômetro no manejo da adubação nitrogenada do capim marandu e do capim Mombaça. PUBVET, 10(11), 844-854. doi: 10.22256/pubvet. v10n11.844-854

Silva, D. R. G., Costa, K., Faquim, V., Oliveira, I., \& Bernardes, T. F. (2013). Doses e fontes de nitrogênio na recuperação das características estruturais e produtivas do capim-Marandu. Revista Ciência Agronômica, 44(1), 184-191. doi: 10.1590/ S1806-66902013000100023

Silva, R. V. M. M., Rossiello, R. O. P., Morenz, M. J. F., Barbieri, E., Jr., Gomes, R. L. T., \& Camargo, S. T., Fo. (2011). Uso de clorofilômetro na avaliação da adubação nitrogenada e potássica no Capim Tifton 85. Revista Brasileira de Saúde e Produção Animal, 12(3), 828-839.

Silveira, P. M., \& Ferreira, E. P. B. (2016). Índice de suficiência de nitrogênio determinado pelo clorofilômetro em feijão inoculado com rizóbio e sob adubação nitrogenada (vol. 1). (Boletim de Pesquisa de Desenvolvimento, 46). Santo Antônio de Goiás, GO: EMBRAPA.

Silveira, P. M., \& Gonzaga, A. C. O. (2017). Portable chlorophyll meter can estimate the nitrogen sufficiency index and levels of topdressing nitrogen in common bean. Pesquisa Agropecuária Tropical, 47(1), 1-6. doi: 10.1590/1983-40632016v4742128

Vilela, L., Soares, W.V., Sousa, D. M. G. \&Macedo, M. C. M. (2004). Calagem e adubação para pastagens. In D. M. G. Sousa, \& E. Lobato (Eds.), Cerrado: correção do solo e adubação (pp.367-382). Embrapa Cerrados, Planaltina.

Villar, F. M. M., Pinto, F. A. C., Fonseca, D. M., Queiroz, D. M., \& Alcântara, G. R. (2015). Sufficiency index for defining nitrogen recommendation in Brachiaria grass pasture. Bioscience Journal, 31(5), 13331340. doi: 14393/BJ-v31n5a2015-26338 